\title{
Stöd eller styrning- En analys av Skolverkets stödmaterial för förskoleklassen
}

\section{Maria Simonsson och Lina Lago, Linköpings universitet}

Sexton år efter att förskoleklassen införs som en egen skolform ger Skolverket ut ett stödmaterial. Vilka bilder av arbetet i förskoleklass och vilken styrning av verksamheten framträder i detta material?

I oktober 2014 gav Skolverket ut ett stödmaterial för förskoleklassen med titeln Förskoleklassen: Uppdrag, innehåll och kvalitet (Skolverket, 2014). Enligt Skolverket är syftet med materialet att "bidra till ökad kunskap om och förståelse för förskoleklassens uppdrag, innehåll och kvalitetsutveckling med utgångspunkt i skollag och läroplan" (ibid. s. 3).

Stödmaterialet ges ut 16 år efter det att förskoleklassen infördes som en egen skolform. Ett stödmaterial som detta kan ses som en del av den officiella retoriken kring utbildningsinstitutionen. Det kan ses som ett försök att åstadkomma förändringsprocesser som ska leda till det bättre. Detta material produceras för lärarna $\mathrm{i}$ förskoleklass som är de som ska realisera detta i de pedagogiska praktikerna. Produktionen av ett nytt stödmaterial för förskoleklassen innebär att det skapas en arena för förhandling, om bilden av barnet och vad det är för institution vi har att göra med. Vi behöver veta mer om vad det är för förhandlingar som uppstår och vilken verksamhet man vill åstadkomma.

Syftet med denna artikel är att få kunskaper om vilka bilder av förskoleklassen och vilka styrningsmekanismer som framträder i Skolverkets stödmaterial (2014). För att göra detta har vi använt Foucaults teorier om styrning (governmentality). Vi vill på detta sätt lyfta fram de sätt på vilka förskoleklassen som utbildningsinstitution och förskoleklasslärarna blir föremål för styrning (Davies \& Harré, 1990; Foucault, 1991, 2003; Rose, 1999).

\section{Förskoleklassens bakgrund och uppdrag}

Vi börjar med att ge en bakgrund till förskoleklassen, dess syfte och uppdrag. För att kunna förstå och analysera Skolverkets (2014) stödmaterial är det viktigt att förhålla sig till detta men också till vad förskoleklassen har blivit under de 16 år den har varit en del av svensk skola.

Förskoleklassen är en särskild skolform som infördes 1998. Det har funnits olika verksamheter för sexåringar tidigare men förskoleklassen skiljer sig från dessa föregångare genom att den omfattas av grundskolans läroplan (Läroplan för grundskolan, förskoleklassen och fritidshemmet 2011: Lgr 11, Skolverket, 2011). 
Att förskoleklassen inrättades kan ses som en konsekvens av 1990-talets politiska diskussioner om tidigareläggning av skolstarten (Regeringens proposition 1995/96:206, 1997/98:6; SOU 2010:67). När förskoleklassen infördes var ett tydligt framskrivet syfte att pedagogiken skulle präglas av ett möte mellan förskolans och skolans traditioner (Regeringens proposition 1997/98:6). Förskoleklassen har också ett tydligt uppdrag att vara skolförberedande (SFS 2010:800) och det finns också forskning som visar att det skolförberedande är en stor del av förskoleklassens verksamhet (Lago, 2014).

Under 2010-talet har diskussionen om tidigare skolstart åter kommit upp på den politiska agendan. Det har kommit politiska förslag om sänkt skolstartsålder och om att göra förskoleklassen obligatorisk. I början av 2014 lade de dåvarande regeringspartierna (c, fp, kd, m) fram ett förslag om en allmän skolstart från sex års ålder (Regeringskansliet, 2014). Även den regering som tillträdde hösten 2014 (mp, s) ville sänka skolstartsåldern genom att göra förskoleklassen obligatorisk (Forssblad \& Jönsson, 2014).

I nuläget finns inga skarpa förslag men både för tidigare och för nuvarande regering har förslagen handlat om att göra den nu frivilliga skolformen förskoleklass obligatorisk. I samband med dessa förslag har politiker också uttalat sig om hur pedagogiken och undervisningen för barn i skolstartsålder bör utformas. Tidigare skolministern Jan Björklund (fp) säger i en intervju att "Det blir mera skolmässigt" (Larsson, 2014) medan nuvarande skolminister Gustav Fridolin (mp) menar att "förskoleklassen måste fortsätta vila på den pedagogik som var grunden när systemet byggdes upp" och svarar ja på frågan om förskolepedagogiken ska vara kvar (Jällhage, 2014).

Mitt i denna politiska diskussion om förskoleklassen och vad den ska vara publicerar Skolverket (2014) förtydligade riktlinjer om förskoleklassens uppdrag. Det gör oss nyfikna på vad det är man från Skolverkets sida menar att förskoleklassen ska vara.

\section{Analys av skolverkets stödmaterial}

I vår analys av Skolverkets (2014) stödmaterial kan vi se att det finns styrningsmekanismer som verkar på både institutionsnivån och på de professionellas nivå. Detta kan sägas innebära en ny blick på eller snarare en omorganiserad sådan, förskoleklassen. Förskoleklassens uppdrag skrivs fram tydligt i texten, där ett förtydligande sker gällande:

1) förskoleklassen som institution (identitet och särdrag) samt

2) hur de professionella kan arbeta (de professionella subjekten).

\section{Styrning av förskoleklassen som institution}

I stödmaterialets bakgrundsdel beskrivs olika forskares resultat som visar hur lärarna i förskoleklasserna har tolkat och realiserat sitt uppdrag. Skolverket pekar på en variation i sättet att arbeta med förskoleklassen. Det finns forskning som visar att den tänkta integrationen eller blandningen av arbetssätt från skolans och förskolans traditioner inte har realiserats. Karlsson et al. (2006a, 2006b) menar att förskoleklassen i stället har blivit skolifierad och att skolans traditioner och undervisningsformer kommit att dominera (se även Axiö, 2001). 
Annan forskning visar att undervisningen i förskoleklassen kan präglas av både förskolans och skolans arbetsformer (Ackesjö, 2013; Kärrby \& Lundström, 2004). I stödmaterialets text legitimeras, med forskningens hjälp, att det finns en mångfald av sätt att bedriva arbetet i förskoleklassen. Detta konstaterande visar att de lokala aktörerna har ett för stort utrymme att tolka hur de ska realisera denna verksamhet, vilket resulterar i en för stor variation. Samtidigt ges också en bild av att förskoleklassens arbete alltmer börjar likna skolans arbetssätt, vilket vi ser som ett slags kritik mot praktiken som framförs i Skolverkets stödmaterial.

Utifrån våra analyser kommer vi att lyfta fram tre områden som vi ser som viktiga i förhållande till Skolverkets styrning.

Det första området handlar om vad det är för institution som förskoleklassen är idag. Vi ser att det i stödmaterialet görs ett försök att homogenisera förskoleklassens verksamhet i landet och därmed styrs och formas också diskursen kring förskoleklassen. Frågan är då: vad är det som styrs för att kunna ge en "enhetlig" verksamhet? I vilka termer kan vi tala om förskoleklassen idag? Det vi kan peka på är att det görs en tydlig definiering av förskoleklassen uppdrag, innehåll och inre arbete, och därmed formas också vilka kunskaper som görs gällande kring förskoleklassen.

Skolverket menar att förskoleklassen inte ska vara skola i traditionell mening. Snarare beskrivs förskoleklassen som en plats där förskolans och skolans pedagogik ska mötas och där lärande snarast ska vara av varierad karaktär, bl.a. betonar man vikten av att arbeta med olika kunskapsuttryck. Det som återkommande lyfts fram i detta material är förskolepedagogiken, leken, estetiken, lärarens kunskap om förskolan och förskolans läroplan (Läroplan för förskolan, Lpfö 98, Skolverket, 2010). Dessa ses som viktiga att förhålla sig till i förskoleklassen och de bör inte utelämnas utan bör ingå i verksamheten. Detta tolkar vi som att det här görs en ledning, guidning och styrning av vad det är för innehåll som är önskvärt i förskoleklassen, nämligen att förskoleklassen är en arena där det arbetas med både skolans och förskolans pedagogik och metoder. Vi tolkar det som en normaliseringsprocess av den pedagogiska praktiken och att man vill styra den pedagogiska praktiken mot att återinföra och betona lek och förskolepedagogik. Det innebär ett återvändande till förskoleklassens historiska rötter, d.v.s. de undervisningsformer för sexåringar som var en del av förskolevärlden.

Det andra området handlar om betoningen av förskoleklassens plats i det livslånga lärandet. En kontinuerlig kunskapsutveckling, där olika utbildningsinstitutioner länkar i, och bygger vidare på, varandras arbete betonas särskilt i Skolverkets stödmaterial.

"Genom att utgå från elevernas erfarenheter, bland annat från förskolan, och arbeta vidare med de övergripande kunskapsmålen i läroplanens andra del kan förskoleklassen möjliggöra en kontinuitet och progression i elevernas utveckling och lärande och vara en länk till skolan." s. 33

Flera gånger i stödmaterialet betonas att förskoleklassens förberedande uppdrag också måste kopplas till kännedom om var barnen kommer ifrån, d.v.s. kunskap om förskolan. Förberedelse handlar inte bara om vad barnen ska förberedas för (grundskolan) utan också vad de har med sig (förskolan). Förskoleklassen konstrueras i stödmaterialet som en övergångspraktik och man har också ett särskilt kapitel om övergångar och 
samverkan. Talet om förskoleklassen som ett möte mellan förskolans och skolans pedagogik kan förstås i ljuset av detta. Genom att förskoleklassen ska stå för en särskild sorts pedagogik ska den utgöra en kontinuitetsskapande praktik där barns erfarenheter från förskolan knyts samman med deras framtid i skolan.

Den tredje aspekten som vi vill lyfta fram är synen på det lärande barnet/eleven. Vi menar att i stödmaterialets text produceras även kunskaper (Foucault, 1982) om barnet. Barn framstår som kompetenta, har kunskaper och erfarenheter med sig från sin förskoletid, och därför bör lärarna i förskoleklassen fortsätta att arbeta utifrån var barnen befinner sig kompetensmässigt för att kunna utgöra "nästa led" i barnens utbildningstrappa. Att forma förskoleklassens praktik på denna institutionsnivå innebär också att forma det lärande subjektet. I detta förtydligande produceras barn/elever som har behov av lek, en lärandemiljö som är lustfylld och som kan erövra världen med lekens hjälp. Det man tydligt gör är att knyta ihop leken och lärandet. Barn/elever i förskoleklass blir några som lär genom lek. På detta sätt kan den pedagogik som förordas ses som barncentrerad. Förskoleklassen ska vara en verksamhet på barnens villkor.

\section{Styrning av professionella}

I Skolverkets stödmaterial läggs stor vikt vid lärarens arbete på olika nivåer, skapandet av lärandemiljöer, användningen av leken som metod i undervisningen, samt vid hur det är att undervisa i förskoleklass. Att vara lärare i förskoleklass innebär något alldeles speciellt, vilket beskrivs på följande sätt:

"Lärare i förskoleklassen har en speciell roll genom att de förväntas vara något som skiljer dem från såväl förskollärare i förskolan som lärare i grundskolan." s. 29

På detta sätt skrivs fram den speciella uppgiften, samt expertområdet för lärarna $\mathrm{i}$ förskoleklassen, och därmed stärks professionen. Att vara lärare i förskoleklass blir att vara en särskild sorts lärare med specifika kompetenser och expertis.

Lärarna i förskoleklass beskrivs samtidigt som några som behöver kunskaper eller som har bristfälliga kunskaper på vissa områden. De behöver "ökad kunskap om och förståelse för förskoleklassens uppdrag" (s. 1). Expertområdet vidgas och balanseras genom att texten lyfter fram att lärarna behöver kunskaper om lek, förskolan och dess pedagogik och läroplan (Skolverket, 2010), samt om skolans läroplan (Skolverket, 2011), inklusive kursplaner. Förskoleklassens lärare förväntas alltså ha kunskap även om dokument och praktiker utanför den egna verksamheten då varken förskolans läroplan eller skolans kursplaner gäller för arbetet i förskoleklass. Detta kopplar vi samman med förskoleklassens roll som en länk mellan förskolan och skolan. Ska man arbeta i en sådan verksamhet antas man behöva ha kunskaper om den verksamhet som barnen kommer ifrån men också om den verksamhet som de ska vidare till. Konsekvensen av detta blir att den lärarroll som Skolverket beskriver är en lärarroll som skiljer sig både från förskollärarens och från grundlärarens. Precis som förskoleklassen beskrivs som en särskild sorts praktik så beskrivs lärarna i förskoleklass som en särskild sorts lärare. 


\section{Sammanfattning och implikationer}

Skolverkets budskap är väldigt tydligt i det att förskolans pedagogik och arbetsmetoder inte får glömmas bort i arbetet i förskoleklass - förskoleklass ska inte enbart vara skola.

Det här dokumentet blir viktigt för lärare i förskoleklass för hur de tolkar och realiserar sitt uppdrag. Genom detta stödmaterial ger Skolverket sin syn på vad förskoleklassen är och bör vara. Genom förtydliganden, goda exempel, experter och diskussionsfrågor konstruerar man den bild av förskoleklassen, förskoleklassläraren och barnet som man från Skolverkets sida förespråkar. På detta sätt blir materialet en styrning mot en homogenisering av hur förskoleklass bör bedrivas.

Det som framstår som viktigt i denna styrning av förskoleklassen är lekens roll för lärande i förskoleklassen samt vikten av att arbeta med varierade former för lärande. Vidare lyfter Skolverket tydligt fram förskoleklassens roll i det livslånga lärandet. För att klara det uppdraget betonas förskoleklasslärares expertis och deras breda kompetenser lyfts fram; en lärare som ska kunna överbrygga skillnader mellan skolformer och bidra till kontinuitet.

Det här innebär att rektorer måste rekrytera och fortbilda en särskild sorts lärare till förskoleklassen för att de ska kunna arbeta med förskoleklassens specifika uppdrag. Särskilt intressant blir detta i förhållande till de lärare som idag utbildas för förskoleklass. Idag är det i hög utsträckning förskollärare som arbetar i förskoleklass. I 2011 års lärarutbildning är det grundlärarna för de tidiga åren som blir behöriga att undervisa i förskoleklass. Det förtydligade uppdraget för förskoleklass innebär att dessa grundlärare måste ha en gedigen kunskap även om förskolans uppdrag och arbetssätt.

\section{Referenser}

Ackesjö, H. (2013). Från förväntningar till motstånd och anpassning: Fyra barns övergångar till och från förskoleklass. Nordic Early Education Research Journal. 6, 1-23.

Axiö, A. (2001). Det rör på sig: Hur gick det när förskoleklass, skola och fritidshem möttes?: Erfarenheter från ett forskningsprojekt. Stockholm: Socialtjänstförvaltningen.

Davies, B. \& Harré, R. (1990). Positioning: The Discursive Production of Selves. Journal of Theory and Social Behaviour. 20:1, 43-63.

Forssblad, M. \& Jönsson, O. (2014, 28 september). S och MP överens om skolan. Sveriges television. Hämtad 2014-11-07, från

http://www.svt.se/nyheter/val2014/socialdemokraterna-och-miljopartiet-overensom-skolan

Foucault, M. (1991). Governmentality. In G. Burchell, C. Gordon, \& P. Miller (red.). The Foucault Effect: Studies in Governmentality. With two Lectures by and an Interview with Michael Foucault (s. 87-104). Chicago: University of Chicago Press.

Foucault, M. (2003). The subject and power. In P. Rabinow and N. Rose (red.). The essential Foucault: Selections from the essential works of Foucault 1954-1984 (s.126144). New York: The new press.

Jällhage, L. (2014, 15 oktober) Nya ministern vill satsa på fritidshem. Lärarnas tidning. Hämtad 2014-11-07, från http://www.lararnasnyheter.se/lararnastidning/2014/10/15/nya-ministern-vill-satsa-pa-fritidshem

Karlsson, M., Melander, H., Pérez Prieto, H. \& Sahlström, F. (2006a). Vad är det att börja skolan?. I M. Karlsson, H. Melander, H. Pérez Prieto \& F. Sahlström (red.).

Förskoleklassen: Ett tionde skolår? (s. 9-26). Stockholm: Liber. 
Karlsson, M., Melander, H., Pérez Prieto, H. \& Sahlström, F. (2006b). En tioårig grundskola?. I M. Karlsson, H. Melander, H. Pérez Prieto \& F. Sahlström (red.). Förskoleklassen: Ett tionde skolår? (s. 166-170). Stockholm: Liber.

Kärrby, G. \& Lundström, M. (2004). Pedagogisk integration och en förändrad praktik. Pedagogisk forskning i Sverige. 9:3, 189-204.

Lago, L. (2014). "Mellanklass kan man kalla det": Om tid och meningsskapande vid övergången från förskoleklass till årskurs ett. Linköping: Linköping University.

Larsson, MJ. (2014, 8 januari) Björklund: Förskoleklass blir mer skolmässig. Dagens nyheter. Hämtad 2014-10-24, från http://www.dn.se/nyheter/politik/bjorklundforskoleklass-blir-mer-skolmassig/

Regeringskansliet (2014). Tre förslag för stärkt grundskola, Promemoria, 2014-01-08.

Regeringens proposition 1995/96:206. Vissa skolfrågor m.m.

Regeringens proposition 1997/98:6. Förskoleklass och andra skollagsfrågor.

Regeringens proposition 2009/10:165. Den nya skollagen: för kunskap, valfrihet och trygghet.

Rose, N.(1999). Powers of Freedom: Reframing political thought. Cambridge: Cambridge University Press.

SFS 2010:800. Skollag. Stockholm: Utbildningsdepartementet.

Skolverket (2010). Läroplan för förskolan: Lpfö 98. Stockholm: Skolverket.

Skolverket (2011). Läroplan för grundskolan, förskoleklassen och fritidshemmet 2011: Lgr11. Stockholm: Skolverket.

Skolverket (2014). Förskoleklassen: Uppdrag, innehåll och kvalitet. Stockholm: Fritzes.

Statens offentliga utredningar, SOU 2010:67. Utredningen om flexibel skolstart $i$ grundskolan. I rättan tid?: Om ålder och skolstart: Betänkande. Stockholm: Skolverket, Fritzes. 